\title{
USE OF GEO-INFORMATION FOR LAND USE PLANNING IN UPPER MAHAWELI CATCHMENT IN SRI LANKA
}

\author{
A Abeywickrema \\ Land Usc Plamning Division
}

This paper presents the results of at study which attempted to evaluate the demand for Ger information of the key decision positions involved with suh-district level planning and decision mating in comparison with the existing supply of spatial information in the Upper Mahawel Watershed Catchnent in Sri Lanka.

The math objective of the paper was to examine the user satisfaction with respect to the seo mormation of selected mapping applications for land use and land potenial and how bu cater fo the demand of key dectston positions of the seciors.

The major lindune of this study shows that as far as the demand of Geo information is concened there are a mumber of government institutions and donor funded projects inolved in sector specific lond use planning and decision making activities at sub-reqional kevel. Also, it was found that here was an increasing demand for accurate reliathe and more up-ro-date, detald infomation specially addressed to their specific sector development.

Where the supply of Gen infomation was concerned there were fiffeen of such applicatoms. Whath cater to the user demand. Some of the products are witely used in projec plaming. edustion and als purpeses while some are specially calceded to the specilic sector development. Where suppliers are concerned it was not only Survey bepartmen wheh provide standardised maps. Seven detaled applications of maps in the study which catered to specilic sector development in relation to land use plamning was found.

In terms of effectiveness and user salisfaction it was found that there were gaps in inlomathon, the scale it has been provided, actual demand and avalability for plamning and decision making in all the sectors.

Finally, the factors or instruments for hetter matching the demand for Geo information with the existing supply of information was identilied.

The results of this study are useful to all the users and suppliers of Geo information who are engaged in mapping. planning. monitoring \& implementation and policy formulation in relation to sector specific land use planning and decision making.

Proceedings of the Fourth Annual Forestry and Environment Symposium 1998 of the Department of Forestry and Environmental Science, University of Sri Jayewardenepura, Sri Lanka 